\title{
Addressing low attainment of children in public care: The Scottish experience
}

\author{
Graham Connelly $^{\mathrm{a}^{*}}$ and Judy Furnivall ${ }^{\mathrm{b}}$ \\ ${ }^{a}$ School of Applied Social Sciences, University of Strathclyde, Glasgow, Scotland; ${ }^{\mathrm{b}}$ Scottish \\ Institute for Residential Child Care, University of Strathclyde, Glasgow, Scotland
}

Policy and practice in relation to the education of looked-after children in Scotland have been significantly influenced as a result of two landmark reports, Learning with Care (2001), and Looked After Children: We Can and Must do Better (2007). This paper provides an account of the main policy developments which are set within the distinctive Scottish legal and educational context. The second report, in particular, has been followed by a more strategic approach to implementing change. There is evidence of considerable infrastructural development, both in the looked-after children sector and more widely in education services. There is also evidence of improvement in outcomes, notably in school attendance and the attainment of children in out of home care. While outcomes generally still lag behind those of children who are not looked after, those of children who are looked after while remaining in the family home remain relatively resistant to improvement. This aspect has been neglected in research so far. It is also not well understood how the policy changes have impacted on organisational change and developments in practice.

Keywords: looked after children; children in public care; education; Scotland

\section{Introduction}

The education of children in public care has been given particular attention by national and local government in Scotland since deficiencies in provision were first identified by an inspection report in 2001 (Her Majesty's Inspectors of Schools and Social Work Services Inspectorate, 2001). This paper provides an explanatory account of the main policy developments in the past decade within the broader context of improving opportunities for looked-after children.

Scotland has always been different from the rest of the UK in relation to education and children's services as a result of its distinctive legal and education systems, and the distinctiveness of these institutions has been important in developing Scotland's approaches to social welfare provision. The law in Scotland developed separately from the law in England and Wales, at least until 1707. Scots law has retained differences because of its different origins, although there are aspects of law which are identical throughout the UK, such as the statutes relating to benefits. Following the introduction in 1999 of devolved government in the UK, distinctive approaches have emerged in policy areas affecting children and families. The Scottish Parliament has the authority to make law in relation to devolved matters and a considerable number of acts and related statutory instruments which affect education and children's welfare services have come into force, of which important examples are the Adoption and Children (Scotland) Act 2007, the Looked after Children 
(Scotland) Regulations 2009, and the Getting it Right for Every Child guidance (Guthrie, 2011; Scottish Government, 2011c).

In Scotland, children in public care, or 'looked-after' children, are principally those for whom the state provides compulsory measures of 'supervision' as defined by the Children

(Scotland) Act 1995, though some children become looked after under voluntary agreements. Compulsory measures are actions taken for the 'protection, guidance, treatment or control' of children under a set of conditions (e.g. lack of parental care, failure to attend school regularly, committing an offence) specified in Section 52 (2) of the Act. In Scotland in 2010, almost 16,000 children were in the care of the state (Scottish Government, 2011a). This figure accounted for $1.4 \%$ of all children up to age 18 across the country, although the proportions of children in state care are higher in the larger cities (for example, 2.8\% in Glasgow). The process of becoming looked after involves a children's hearing, at which a panel of three volunteer members of the community considers background reports and listens to the views of the child, family members and professionals. If the panel concludes that compulsory measures of care are necessary it will specify whether these should be provided 'at home', i.e. with the child remaining in the usual family home ( $40 \%$ of all looked after children) or 'away from home'. Half of all children looked after away from home live in family-type settings, either with trained foster carers or potential adoptive parents, or in so-called 'kinship' settings where a member of the close or extended family is officially recognised as the main carer. A minority $(10 \%)$ of looked-after children is cared for in group settings, including residential homes in the community (also called 'units', young people's centres or children's houses), residential schools and secure care settings. This figure is an average, however, and when age is taken into account it is evident that foster care is more common as a placement for younger children and residential care for older children. For example, 20\% of 12-15 year old looked after children live in residential settings, compared with less than three percent of 5-11 year olds and a negligible proportion of under-fives. The overall proportion of looked after children cared for in group settings has been falling over a period of many years in comparison with increasing proportions of children living in foster and kinship placements. For example, in 1976, while $36 \%$ of looked-after children lived in residential settings, $22 \%$ were in foster care.

Evidence of low attainment by children in public care, and the related lack of attention to education by professionals, was first highlighted in England by Sonia Jackson (Jackson, 1987). The concerns have since become a significant aspect of public policy within the different UK administrations (Department of Education and Skills, 2007; Department of Health Social Services and Public Safety Northern Ireland, 2007; Scottish Executive, 2007; Welsh Assembly Government, 2007). Indeed these are matters of concern throughout Europe, notably in relation to the perceived role of education in breaking the intergenerational transmission of poverty, since it is typically children at risk of poverty who are also at risk of becoming looked after by public agencies (European Commission, 2008, 2009).

It was some years before the concerns raised by Jackson began to influence research and policy development in Scotland, although, once begun, the attention of academics, policymakers and practitioners was quickly mobilised. The rapid pace of development was 
probably a function of a combination of the small country effect, the prominence given to education and children's services within devolved government and the significant development of civil servant capacity since 1999. The origins of specifically Scottish interests in the education of children in care - a group now referred to as 'looked-after children' - came with the publication of a study highlighting a tendency to concentrate on behaviour rather than academic performance in child care reviews (Francis, Thomson, \& Mills, 1996) and of a review of research, policy and practice (Borland, Pearson, Hill, \& Bloomfield, 1998).

Two government reports are key markers of policy and practice development. The first reported on the inspection of the education of 50 children in residential care settings in five of Scotland's 32 local authorities (Her Majesty's Inspectors of Schools and Social Work Services Inspectorate, 2001; Maclean \& Gunion, 2003). The Learning with Care report contained nine recommendations, such as the advice that 'local authorities should develop an integrated policy covering education and social work which ensures that the educational needs of looked after children are met effectively' (p.34).

The second report, Looked After Children \& Young People: We Can and Must do Better, was published six years later when the issue of the education of children in care settings had become a matter of significant political concern and a substantial knowledge base had been developing as a result of the dissemination of guidance for practice, professional training, conferences, seminars and research (Scottish Executive, 2007). The report's 19 actions emphasised the crucial link between wellbeing and success in education and had four distinctive features. First, it was published by the government itself, rather than by a quasigovernmental body, and consequently had greater authority. Second, it was framed to emphasise the rights of looked-after children to the same prospects envisaged for all of Scotland's children, and therefore the concerns about education and attainment were set within broader parameters of wellbeing and aspiration. Third, it was concerned with lookedafter children in all settings, in contrast to the earlier report's focus solely on children in residential care. This aspect was significant for the report's capacity to influence policy and practice, since around 40\% of Scotland's 16,000 looked-after children receive support whilst remaining in the family home. Fourth, the report adopted, for the first time in an official document in Scotland, the concept of 'corporate parent,' a term encapsulating the obligations of local authorities sharing the parenting of looked-after children. Both reports will be considered further later in this paper.

Concerns about the wellbeing of looked-after children in Scotland are set within a broader social policy context which while being interpreted for the legal and cultural characteristics of Scotland derive from contemporary international aspirations for improving rights and social justice for children (Gudbrandson, 2007; Scottish Executive, 1999; UN General Assembly, 1989). These aspirations include defining and extending citizenship rights, combating social exclusion, tackling inequalities and seeking to overcome barriers to accessing services. In relation to the educational opportunities and attainment of disadvantaged groups, the discourse of social justice which encompasses concepts such as values, life-skills and empowerment, is particularly relevant (Hoskins, 2008). 
This paper therefore argues that the conditions for improving services for looked-after children, particularly in respect of their rights to a good education and better prospects in post-school education and employment, have been considerably advanced by several aspects of policy and practice change. Three particular aspects - the origins of government intervention, the developing policy landscape, and the training of workers - are discussed in this paper, and these are related to the educational outcomes of looked-after children.

\section{The origins of government intervention}

The Learning with Care report was arguably successful in three particular ways. First, it pinpointed significant weaknesses in relation to the support in education for children who had been removed from the family home with the aim of improving their welfare. For example, statutory care plans were found to be of varying quality, or were missing; they typically included little useful information about education, and were not routinely shared with schools. These deficiencies were also found in a later file audit of care plans (Vincent, 2004). Second, through its recommendations, the report highlighted features of good practice. Third, it set in train a sequence of policy and practice reforms which are continuing 10 years later. For example, one of the recommendations called for 'joint professional development for education and social work staff and carers' (p.34) and this resulted in the Learning With Care: Improving Outcomes for Looked After Children Project. The project produced a range of products including training materials, a report based on consultations with children in care about their educational experiences (Ritchie, 2003), an information booklet aimed at carers, social workers and teachers (Connelly, McKay, \& O'Hagan, 2003) and a set of quality indicators designed to be used within the general framework of school self-evaluation ${ }^{\mathrm{i}}$ but aimed at all partners in children's services (Her Majesty's Inspectorate of Schools, 2003). The process of development of these materials has been outlined in more detail elsewhere (Connelly, 2003; Furnivall \& Hudson, 2003).

Another example of government intervention led to an attempt to provide cash support directly to children in out of home care. A total of $£ 10 \mathrm{~m}$ was paid to local authorities, based on the allocation of $£ 500$ per child looked after 'in a family home' and $£ 2,500$ for each child in residential homes, schools and secure accommodation (Scottish Executive, 2001). The intention of the fund was to influence attainment by providing books, computer equipment and homework materials. As a strategy it was somewhat naïve. While the additional funding was welcomed, there were also criticisms of the approach for being short-term, rushed and non-sustaining. A report prepared by the charity Who Cares? Scotland indicated that of 170 young people surveyed, 98 (58\%) were unaware that money had been invested in their education and few had been given a say in the spending (Boyce, 2004).

As a result of such criticism, the publication of the 2007 report, Looked After Children \& Young People: We Can and Must do Better, was followed by the establishment of a highlevel committee sitting during 2007-2008, and short-life working groups, to oversee the implementation of the report's recommendations. This strategic approach to influencing 
change was more effective and the government established a further strategic planning group which began working in the autumn of 2010. A review of Scotland's residential child care services (the National Residential Child Care Initiative) proposed time-limited 'activity hubs' to take forward recommendations in respect of workforce development, commissioning of services, and physical and mental health (Bayes, 2009). While accepting the review's main recommendations, the government broadened the scope of implementation to encompass the needs of looked-after children living in all settings, and also to give the 'hubs' - care planning, workforce commissioning, improving health outcomes and improving learning outcomes - more status and a definitive strategic planning role by establishing a high-level governance group which has adopted an open approach to its work by making its working papers publicly available ${ }^{\mathrm{ii}}$.

\section{The developing policy landscape}

The policy landscape in relation to the education of looked-after children in Scotland can be characterised by two types of output: the first type are reports or guidance documents which are specifically dedicated to the task of outlining the needs of looked-after children and good professional practice; the second type are documents not exclusively concerned with lookedafter children but which have incorporated the needs of looked-after children into their content.

In the first category are policy documents concerned with education and achievement; additionally there are documents concerned with health needs, though these are not discussed here. The report, Looked After Children \& Young People: We Can and Must do Better, identified the problems and made proposals for improvements (Scottish Executive, 2007). There are two particular features of the report which are noteworthy. The first is its uncompromising tone, evident in the choice of title, the explicitness with which the actions are stated and the rather unusual inclusion of paragraphs within the report's sections giving the Ministerial working group's reactions to the evidence presented to them.

\footnotetext{
Thus the group was shocked at how highly looked after children and young people feature in the exclusion rates from school. They felt that whilst it is important that head teachers retain the right to exclude disruptive pupils, schools also need to be aware of the many challenges and obstacles looked after children and young people face; schools need to deal with looked after children and young people's behaviour in, and attitudes to, school with sensitivity (ibid., p. 23).
}

The second began life as a simple cosmetic feature, but has come to have significant utility. The government's printers used a blue, green and pink colour scheme with a distinctive spiral motif on the cover and this design was subsequently used to identify all documents emanating from the Scottish Government Looked After Children Branch. This was a deliberate action to make the materials instantly recognisable and more easily accessible, and also to encourage inter-professional collaboration by using a neutral brand which was not associated with a single professional group.

Detailed guidance on the responsibilities of agencies sharing parental responsibilities is provided in These are our Bairns ${ }^{i i i}$ : A Guide for Community Planning Partnerships on being 
a Good Corporate Parent (Scottish Government, 2008c). This policy guide introduces the notion of the wider 'corporate family' and 14 of its 17 chapters outline actions and outcome measures for services.

The schools' inspectorate report, Count Us In: Improving the Education of Looked After Children, part of a series of reports dealing with different aspects of inclusive education, was based on fieldwork in 15 local authorities, with the specific aims of investigating provision for children at risk of missing out on education and identifying good practice and barriers to progress (Her Majesty's Inspectorate of Education, 2008). The report highlighted teachers' lack of awareness of which pupils were looked after, and ineffective systems for tracking children and their attainment, particularly in the case of those receiving services while living in the family home. The inspectors reported positively on progress made in relation to the development of integrated policies on looked-after children involving education and social work agencies, and on the provision of professional development opportunities for staff. The report was followed by the publication of a tool for evaluating services for looked-after children, How Good is Our Corporate Parenting, which makes clear that local authorities have obligations to evaluate the quality of the educational environment that goes beyond the school and into the placement setting (Her Majesty's Inspectorate of Education, 2009).

The practice guide, Core Tasks for Designated Managers in Educational and Residential Establishments in Scotland (Scottish Government, 2008a), details the responsibilities of corporate parents in respect of education, identifying 27 'core tasks'. Two important features of the guide demonstrate how thinking about policy in relation to looked-after children has progressed in Scotland since 2003. First, guidance was provided for the entire spectrum of education, from early years to further and higher education. Second, the designated manager role was extended to encompass residential children's homes and residential schools.

Despite the increasing amount of attention given to addressing the educational needs of looked-after children, researchers have highlighted deficiencies in data collection, particularly in relation to attainment and in longer-term tracking of the progress of individual children (Brodie, 2010; Connelly et al., 2008; Jacklin, Robinson, \& Torrance, 2006; Jackson $\&$ Martin, 1998). The Educational Outcomes of Scotland's Looked After Children and Young People: A New Reporting Framework introduced changes in the method of data collection (Scottish Government, 2009c). The reporting period shifted from the financial year to the academic year to permit more accurate comparisons to be made between looked-after children and non-looked-after children; previously data reported have been based on a census of children looked after on a single date, 31 March. Future reports will also include only those children who have been looked after for the entire academic year. The second change made provision for the use of a unique reference number to help improve the accuracy of data collection. This device should allow a greater degree of monitoring, with the possibility of longitudinal tracking of the progress of cohorts of looked-after children for research and of individual children for professional purposes. A third, but more problematic, potential change relates to the desirability of sharing data collected by different agencies (e.g. education, social services, health and children's hearings), a matter of much concern to politicians (Scottish Parliament Public Audit Committee, 2011). 
Earlier in this paper a distinction was made between policy outputs which are exclusively about looked-after children and those which have incorporated the needs of looked-after children into their content. Two examples of the latter are presented because of their potential importance for influencing practice.

The Education (Additional Support for Learning) (Scotland) Act 2009 amended the law in respect of school placing requests for children with additional support needs in education. One provision gave legal force to the presumption that looked-after children should have 'additional support' in relation to their education.

...a child or young person has additional support needs if the child or young person is looked after by a local authority (within the meaning of section 17(6) of the Children (Scotland) Act 1995 (c36).

The result is that there is an entitlement to assessment of additional support needs where a child or young person is looked after by the state. This entitlement is spelled out in a new code of practice for professionals, Supporting Children's Learning (Scottish Government, 2010b).

In discharging their responsibilities towards looked after children and young people authorities are obliged to take steps to consider the educational progress of these children and young people. These steps should include establishing whether looked after children and young people require additional support to enable them to benefit from school education and which of those with additional support needs meet the requirements for having a co-ordinated support plan (p.14) ${ }^{\mathrm{iv}}$.

The proponents of statutory intervention argued that too often looked-after children did not receive appropriate support for their education (Francis, 2008). This view prevailed but a contrary view has been voiced by some practitioners who argue that it is wasteful of resources to prove additional supports are not required in the case of looked-after children apparently coping well in school. The education inspectorate indicated that the additional support needs of looked-after children continued to be inconsistently addressed, particularly in the case of children looked after at home and in kinship care (Her Majesty's Inspectorate of Education, 2010).

The second example is Included, Engaged and Involved: A Positive Approach to Managing School Exclusions which provides detailed information, covering six pages, about lookedafter children, the impact of exclusion on their lives, advice about avoidance of exclusion and the procedures which must be followed if exclusion is judged to be unavoidable (Scottish Government, 2011b). The previous advice on exclusion, issued in 2003, included only a single sentence about looked-after children and the tenor of the guidance put the decisionmaking power almost exclusively in the hands of the school. This simple metric is evidence of the extent to which the rights of looked-after children to receive a consistent schooling have become recognised within the broader educational community. 


\section{The training of workers}

Looked After Children \& Young People: We Can and Must do Better gave a commitment to improve opportunities for access to training for parents, foster carers, residential workers, teachers - including teachers in training - social workers and health workers. Training for professionals, particularly inter-disciplinary training, had begun as a result of the recommendations of Learning with Care (Her Majesty's Inspectors of Schools and Social Work Services Inspectorate, 2001). The 2007 report provided an opportunity to reinforce messages about training needs and to take advantage of advances in educational technology. Therefore, multi-media training materials, which included a specially-commissioned film, Craig's Story, dramatising the effects on education of a young child becoming looked after as a result of neglect and abuse, were developed and produced in DVD-ROM format (Furnivall, Connelly, Hudson, \& McCann, 2008). The interactive DVD was designed for individual study or for use in courses, and several course options were provided, including a short briefing seminar and a full three-day course.

More than 20,000 copies of the DVD were distributed within children's services during 200809, for example to every educational establishment in Scotland, from nurseries to universities and approximately 200 staff were briefed as trainers to cascade training sessions within local authorities and other agencies. An information leaflet for teachers and related professionals was prepared to support training and was hosted on the website of the teachers' registration body, the General Teaching Council for Scotland, an illustration of co-operation between institutions aimed at raising awareness (Scottish Government, 2008b).

In a further example of inter-agency collaboration, a national looked-after children website was created, provided as a micro-site located within the main website of the national curriculum support agency, Learning and Teaching Scotland. ${ }^{\mathrm{v}}$ The aim of the website is to provide a portal to information, guidance, reports and good practice examples for relevant professionals, carers and parents, with linkage to the support materials in the main website, including those in another micro-site, ParentZone. References to 'parents' in this area were changed to the more inclusive wording, 'parents and carers'.

The Learning with Care report had advocated that residential children's homes should aspire to be educationally rich environments.

As part of their quality assurance procedures local authorities should undertake an audit of their residential units to assess how far they are educationally rich environments and, where shortcomings are found, make plans to take appropriate action(Her Majesty's Inspectors of Schools and Social Work Services Inspectorate, 2001, p. 37).

The concept of the educationally rich environment is useful in countering un-stimulating intellectual conditions and low educational expectations of looked-after children, barriers to attainment which have been highlighted by many observers over the years (Berridge, 1985; Berridge \& Brodie, 1998; Jackson \& McParlin, 2006; Kahan, 1994). The dissemination of information about looked-after children, in all settings, particularly about their additional support needs in education, as well as further training for designated managers and other children's services' professionals with specialist roles, provides the basis for improvement 
and there is compelling evidence that focusing on education can be effective in improving outcomes (Brodie, 2010; Centre for Excellence and Outcomes in Children's Services, 2008; Gallagher, Brannan, Jones, \& Westwood, 2004). Raising awareness among workers has been mirrored by care standards ${ }^{\mathrm{vi}}$, drawing attention to the rights of children to receive good educational experiences and have adequate study facilities, including access to computers and the internet.

\section{Is there evidence of improvement?}

The preceding sections of this paper have presented evidence in support of the proposition that policy and governance innovations have demonstrated the serious intentions of politicians and children's services' professionals to improve the educational outcomes for looked-after children in Scotland. This is clearly a long-term commitment and improvements in attainment, access to post-school education and employment prospects cannot be expected to follow immediately, or dramatically. Also, official statistics tell only part of the story, since they cannot communicate the experiences of individual children and their carers and teachers. They tend to emphasise inadequacies and also to hide the achievements of lookedafter children which may take longer to develop and in many cases will have taken more circuitous paths than those of more advantaged children (Duncalf, 2010; Happer, McCreadie, \& Aldgate, 2006). Nevertheless, statistics are useful in pointing to trends and highlighting concerns. This section of the paper, therefore, examines information published in government statistical reports in respect of the education of looked-after children and considers whether these provide evidence that efforts in policy development and awareness-raising are beginning to make an impact on standard outcome measures.

\section{School attendance}

Unsurprisingly, there is a positive relationship between attendance at school and attainment, shown, for example, in a large scale study of schools in Ohio, USA (Roby, 2004). Lookedafter children in Scotland had almost twice the average number of absences from school in 2008-09 as those not looked after: 45.0 half days compared with 25.0 (Scottish Government, 2009a). But it is the absence from school of children looked after 'at home' (average number of half days' absence $=58.7$ ) which accounts significantly for the poor overall outcome, while children looked after in out of home care settings (residential, foster and kinship care) have absences only a little higher than their non-looked-after peers (28.1 half days compared with 25.0). Table 1 shows the percentage attendance at school of looked-after children during the period 2003-04 to 2009-10, compiled from official Scottish Government annual reports. What is evident is the considerable improvement in attendance of children looked after in out of home care settings, while those looked after at home continue to have significantly poorer attendance at school. It seems reasonable to conclude that carers are as effective as the parents of non-looked-after children at ensuring that children attend school. 
[Table 1 about here]

\section{Exclusion from school}

The rate at which they are excluded from school provides an indication of the disruption of education experienced by some looked-after children. Students can be excluded from school for behaviour regarded as unacceptable, following a formal procedure. The most common reasons for exclusion are 'general or persistent disobedience' and 'verbal abuse of staff,' accounting for 58\% of all cases of temporary exclusions in 2008/9 (Scottish Government, 2010c). Most exclusion occurs for short periods of up to three days before the student returns to the same school, though some are considerably longer. Table 2 shows temporary exclusions of looked-after children in Scotland over a seven-year period.

[Table 2 about here]

The rates of exclusion of both looked-after and non-looked-after children rose from 2003-04 and peaked in 2006-07. One explanation is that this is indicative of an increase in indiscipline in schools. Nevertheless the fall in rates noted in the following two years parallels official intolerance of exclusion as a remedy for in-school behaviour problems. What is also obvious from the table is the significantly higher rate of exclusion of looked-after children. The method of calculating the rate of exclusion of looked-after children changed in 2007-08 and the more recent statistics are regarded by government statisticians as being more accurate. For this reason 2007-08 will be the index year for future comparisons. The 2008-09 figures show a substantial fall on the previous year, and although welcome it is too soon to know if this is the beginning of improvement. A second observation is that the exclusion rate for those looked after away from home was consistently and appreciably higher than for the at home category until 2007-08, when the trend reversed. The most recent figures showing higher exclusion rates for children looked after at home are consistent with other poorer outcomes for this group. The change in the method of collection does not explain the apparently higher rates for those looked after away from home in the earlier statistics. One anecdotal explanation, which cannot be verified, is that schools may have been more inclined to exclude a looked-after pupil where a foster or residential carer was readily available. If this is a likely explanation, perhaps the practice is also now less likely to occur as a result of better briefing and exposure to training.

\section{Attainment}

A standard measure of attainment that has been reported annually is 'the academic attainment of young people aged 16 or over who ceased to be looked after during the year'. Table 3 shows a comparison of the percentages of care leavers on three metrics - those gaining no awards as a result of taking external examinations administered by the Scottish Qualifications' Agency (SQA) ${ }^{\mathrm{vii}}$, those who gained at least one award at the most basic level (known as SCQF Level $3^{\text {viii }}$ ) or higher, and those gaining awards in both English and mathematics at the most basic level or higher - in 2003, 2006 and 2008 (Scottish Executive, 
2003, 2006; Scottish Government, 2010a). The most striking feature of this table is the high proportion of care leavers who gained no qualifications by the time they left school compared with 3.3\% of all children in Scotland who left school in 2008 without qualifications (Scottish Government, 2010d). Also evident is the significantly lower attainment of young people looked after away from home, compared to those placed in out of home care. Nevertheless, the table shows encouraging signs of non-trivial improvement in attainment during this relatively short five-year period.

[Table 3 about here]

\section{Conclusion}

The low attainment of looked-after children in Scotland persists and therefore it remains an important cause for public concern and an embarrassing indicator of social injustice in a country which is traditionally proud of its strong commitment to education and the rights of children. The low attainment is reflected in the small proportion of looked-after children progressing directly from school to higher education - around three percent of all looked-after children, compared with $36 \%$ of non-looked after children - and the high proportion who are neither in education nor in employment upon leaving school - 36\% compared to $11 \%$ of nonlooked-after children (Scottish Government, 2009b).

There is evidence in official statistics to show that in relation to attendance and attainment the trend in Scotland is beginning to move in the right direction, even if the gap between lookedafter children and their non-looked-after peers is still unacceptably large. This change is also consistent with improvements noted in England (Brodie, 2010). In Scotland, children living in out of home care, looked after by residential, foster and kinship carers, now have school attendance which is as good as that achieved by children who are not looked after. Almost half of this sub-set of looked-after children now leaves school with a qualification in both mathematics and English, the proportion having increased from $41 \%$ to $46 \%$ of the cohort in just two years. The careers agency, Skills Development Scotland, has not so far distinguished between the categories looked after at home and away from home in its reports of destination surveys; if it did these would undoubtedly show improvements in entry to further and higher education from the out of home care group. These findings provide evidence of the advantages conferred by out of home care; for example, Forrester et al., in a review of 12 studies in England and Wales, concluded that while children who entered public care tended to have serious problems, their welfare typically improved over time (Forrester, Goodman, Cocker, Binnie, \& Jensch, 2009). It is important that this message is understood by politicians and practitioners who would argue for a reduction in the use of out of home care for financial or ideological reasons.

It is also clear that significantly more effort should be made to understand the particular support needs in education of children looked after while remaining in the family home and this aspect needs to be given substantially greater attention by researchers so that there is a secure basis for developing practice. This observation also raises important questions, 
answers to which should inform a debate about the consequences, particularly in terms of educational attainment, of maintaining children at home in circumstances which are stressful and chaotic.

Children become looked after because of neglect and trauma and the developmental effects of such assaults on childhood, combined with disrupted school attendance, inevitably affect progress in education and eventual attainment. As this paper has shown, there has been considerable investment in the past decade in Scotland in developing the policy and practice infrastructure needed to support improvement. There is evidence of improvement in outcomes. What is not well understood is how the policy changes have impacted on organisational change and developments in practice. Better understanding is needed to ensure that the improvement trajectory is both maintained and accelerated.

\section{References}

Bayes, K. (2009). Higher aspirations, brighter futures: National residential child care initiative overview report. Glasgow: SIRCC.

Berridge, D. (1985). Children's homes. Oxford: Basil Blackwell.

Berridge, D., \& Brodie, I. (1998). Children's homes revisited. London: Jessica Kingsley.

Borland, M., Pearson, C., Hill, M., \& Bloomfield, I. (1998). Education and care away from home: A review of policy, practice and research. Edinburgh: Scottish Council for Research in Education.

Boyce, P. (2004). A different class? Educational attainment: The views and experiences of looked after young people. Glasgow: Who Cares? Scotland.

Brodie, I. (2010). Improving educational outcomes for looked after children and young people. London.

Centre for Excellence and Outcomes in Children's Services. (2008). Narrowing the gap. London.

Connelly, G. (2003). Developing quality indicators for learning with care. Scottish Journal of Residential Child Care, 2(2), 69-78.

Connelly, G., Forrest, J., Furnivall, J., Siebelt, L., Smith, I., \& Seagraves, L. (2008). The educational attainment of looked after children local authority pilot projects: Final research report. Edinburgh: The Scottish Government Retrieved from http://www.scotland.gov.uk/Publications/2008/09/12095701/0. 
Connelly, G., McKay, E., \& O'Hagan, P. (2003). Learning with care: Information for carers, social workers and teachers concerning the education of looked after children and young people. Retrieved from www.hmie.gov.uk/documents/publication/5679text.pdf.

Department of Education and Skills. (2007). Care matters: Time for change. London: Department of Education and Skills Retrieved from http://www.officialdocuments.gov.uk/document/cm71/7137/7137.pdf.

Department of Health Social Services and Public Safety Northern Ireland. (2007). Care matters in Northern Ireland: A bridge to a better future. Belfast: Northern Ireland Assembly Retrieved from http://www.dhsspsni.gov.uk/care-matters-ni-3.pdf.

Duncalf, Z. (2010). Listen up! adult care leavers speak out: The views of 310 care leavers aged 17-78. Retrieved from http://www.careleavers.com/research

European Commission. (2008). Child poverty and well-being in the EU: Current status and way forward. Luxembourg: European Commission.

European Commission. (2009). Eurobarometer survey on poverty and social exclusion. Luxembourg: Publications Office of the European Union.

Forrester, D., Goodman, K., Cocker, C., Binnie, C., \& Jensch, G. (2009). What is the impact of public care on children's welfare? A review of research findings from England and Wales and their policy implications. Journal of Social Policy, 38(3), 439-456. doi: $10.1017 / \mathrm{S} 0047279003110$

Francis, J. (2008). Developing inclusive education policy and practice for looked after children. Scottish Journal of Residential Child Care, 7(1), 60-70.

Francis, J., Thomson, G. O. B., \& Mills, S. (1996). The quality of the educational experience of children in care. Edinburgh: University of Edinburgh.

Furnivall, J., Connelly, G., Hudson, B., \& McCann, G. (2008). Looked after children and young people: We can and must do better training materials DVD-ROM. Edinburgh: The Scottish Government.

Furnivall, J., \& Hudson, B. (2003). The learning with care training materials. Scottish Journal of Residential Child Care, 2(2), 63-68.

Gallagher, B., Brannan, C., Jones, R., \& Westwood, S. (2004). Good practice in the education of children in residential care. British Journal of Social Work, 34(8), 1133-1160. doi: $10.1093 / \mathrm{bjsw} / \mathrm{bch} 133$

Gudbrandson, B. (2007). Rights of children at risk and in care. Paris: Council of Europe Publishing. 
Guthrie, T. (2011). Social work law in Scotland (3rd ed.). Haywards Heath: Bloomsbury.

Happer, H., McCreadie, J., \& Aldgate, J. (2006). Celebrating success: What helps looked after children succeed. Edinburgh: Social Work Inspection Agency Retrieved from http://www.scotland.gov.uk/Publications/2006/06/07121906/1.

Her Majesty's Inspectorate of Education. (2008). Count us in: Improving the education of our looked after children. Edinburgh: HMIE Retrieved from http://www.hmie.gov.uk/documents/publication/cuiielac.pdf.

Her Majesty's Inspectorate of Education. (2009). Improving services for children: How good is our corporate parenting? Edinburgh: HMIE Retrieved from http://www.hmie.gov.uk/documents/publication/ischgiocp.pdf.

Her Majesty's Inspectorate of Education. (2010). Review of the Additional Support for Learning Act: Adding benefits for learners. Edinburgh: HMIE Retrieved from http://www.hmie.gov.uk/documents/publication/raslaabl.pdf.

Her Majesty's Inspectorate of Schools. (2003). Inclusion and equality. Part 1: Evaluating education and care placements for looked after children and young people. HMIE Retrieved from http://www.hmie.gov.uk/documents/publication/hgioslac.pdf.

Her Majesty's Inspectors of Schools and Social Work Services Inspectorate. (2001). Learning with care: The education of children looked after away from home by local authorities. Edinburgh: HMI and SWSI Retrieved from http://www.scotland.gov.uk/library3/education/lacr-00.asp

Hoskins, B. (2008). The discourse of social justice within European education policy developments: The example of key competences and indicator development towards assuring the continuation of democracy. European Educational Research Journal, 7(3), 319-330. doi: 10.2304/eerj.2008.7.3.319

Jacklin, A., Robinson, C., \& Torrance, H. (2006). When lack of data is data: Do we really know who our looked-after children are? European Journal of Special Needs Education, 21(1), 1-20. doi: 10.1080/08856250500491773

Jackson, S. (1987). The education of children in care. Bristol: School of Applied Social Studies, University of Bristol.

Jackson, S., \& Martin, P. Y. (1998). Surviving the care system: education and resilience. Journal of Adolescence, 21, 569-583.

Jackson, S., \& McParlin, P. (2006). The education of children in care. The Psychologist, 19(2), 90-93.

Kahan, B. (1994). Growing up in groups. London: HMSO. 
Maclean, K., \& Gunion, M. (2003). Learning with care: The education of children looked after away from home by local authorities. Adoption \& Fostering, 27(2), 20-31.

Ritchie, A. (2003). Care to learn? The educational experiences of children and young people who are looked after. Edinburgh: Save the Children and Who Cares? Scotland.

Roby, D. E. (2004). Research on school attendance and student achievement: A study of Ohio schools. Educational Research Quarterly, 28(1), 3-16.

Scottish Executive. (1999). Social justice: A Scotland where everyone matters. Edinburgh: The Scottish Executive Retrieved from http://scotland.gov.uk/Publications/1999/11/4174/File-1.

Scottish Executive. (2001). Special schoolbooks fund for kids in care: News release SE4195/2001 Retrieved 10 February, 2007, from http://www.scotland.gov.uk/pages/news/2001/10/SE4195.aspx

Scottish Executive. (2003). Children's social work statistics 2002-03. Edinburgh: The Scottish Executive Retrieved from http://www.scotland.gov.uk/Publications/2003/10/18459/28599.

Scottish Executive. (2006). Children looked after 2005-06. Edinburgh: The Scottish Executive Retrieved from http://www.scotland.gov.uk/Publications/2006/12/08105227/0.

Scottish Executive. (2007). Looked after children \& young people: We can and must do better. Edinburgh: The Scottish Executive Retrieved from http://www.scotland.gov.uk/Publications/2007/01/15084446/0

Scottish Government. (2008a). Core tasks for designated managers in educational and residential establishments in Scotland. Edinburgh: Retrieved from http://www.scotland.gov.uk/Publications/2008/09/09143710/0.

Scottish Government. (2008b). Looked after children and young people: Working together to improve outcomes. Retrieved from http://www.gtcs.org.uk/web/FILES/FormUploads/looked-after-children-and-youngpeople1660_222.pdf

Scottish Government. (2008c). These are our bairns: A guide for community planning partnerships on being a good corporate parent. Edinburgh: The Scottish Government Retrieved from http://www.scotland.gov.uk/Publications/2008/08/29115839/0.

Scottish Government. (2009a). Attendance and absence in Scottish schools 2008/09. Edinburgh: The Scottish Government Retrieved from http://www.scotland.gov.uk/Publications/2009/12/08155629/0 
Scottish Government. (2009b). Destinations of leavers from Scottish schools 2008/09.

Edinburgh: The Scottish Government Retrieved from

http://www.scotland.gov.uk/Publications/2009/11/20112425/0.

Scottish Government. (2009c). The educational outcomes of Scotland's looked after children and young people: A new reporting framework. Edinburgh: The Scottish Government Retrieved from http://www.scotland.gov.uk/Publications/2009/09/16092427/0.

Scottish Government. (2010a). Children looked after statistics 2008-09. Edinburgh: The Scottish Government Retrieved from http://www.scotland.gov.uk/Publications/2010/02/22133946/0.

Scottish Government. (2010b). Code of practice: Supporting children's learning: Statutory guidance relating to the Education (Additional Support for Learning) (Scotland) Act 2004 as amended. Edinburgh: The Scottish Government Retrieved from http://www.scotland.gov.uk/Publications/2010/08/11140218/0.

Scottish Government. (2010c). Exclusions from schools 2008/09. Edinburgh: The Scottish Government Retrieved from http://www.scotland.gov.uk/Publications/2010/11/03094708/0.

Scottish Government. (2010d). SQA attainment and school leaver qualifications in Scotland 2008/09. Edinburgh: The Scottish Government Retrieved from http://www.scotland.gov.uk/Publications/2010/03/22111037/3.

Scottish Government. (2011a). Children looked after statistics 2009-10. Edinburgh: The Scottish Government Retrieved from http://www.scotland.gov.uk/Publications/2011/02/18105352/0.

Scottish Government. (2011b). Included, engaged and involved: A positive approach to managing school exclusions. Edinburgh: The Scottish Government Retrieved from http://www.scotland.gov.uk/Publications/2011/03/17095258/0.

Scottish Government. (2011c). The vital importance of getting it right for every child and young person. Edinburgh: The Scottish Government Retrieved from http://www.scotland.gov.uk/Publications/2011/01/11143648/0.

Scottish Parliament Public Audit Committee. (2011). Getting it righ for children in residential care: SP paper 586. Edinburgh: The Scottish Parliament Retrieved from http://www.scottish.parliament.uk/s3/committees/publicAudit/reports-11/paur11$\underline{03 . h t m \# 13 .}$. 
UN General Assembly. (1989). Convention on the rights of the child. Geneva: OHCHR.

Vincent, S. (2004). Looking after children in Scotland: Good parenting, good outcomes: Report on file audit of local authorities' use of looking after children materials. The Scottish Executive Retrieved from http://www.scotland.gov.uk/Publications/2004/06/19439/38253.

Welsh Assembly Government. (2007). Towards a stable life and a brighter future. Cardiff: Welsh Assembly Government Retrieved from http://www.wlga.gov.uk/uploads/publications/2877.pdf. 
Table 1: Attendance of looked-after children: 2003-04 to 2009-10. Figures show actual half days' attendance, possible half days' attendance and percentage attendance (in brackets).

\begin{tabular}{|c|c|c|c|c|c|c|c|}
\hline & $2003-2004$ & $2004-2005$ & $2005-06$ & $2006-2007$ & $2007-2008$ & $2008-2009$ & $2009-2010$ \\
\hline $\begin{array}{l}\text { Looked after at } \\
\text { home }\end{array}$ & $\begin{array}{l}741289 \\
875506 \\
(84.7)\end{array}$ & $\begin{array}{l}8695588 \\
1039386 \\
(83.7)\end{array}$ & $\begin{array}{l}1148114 \\
1353838 \\
(84.8)\end{array}$ & $\begin{array}{l}1289172 \\
1542660 \\
(83.6)\end{array}$ & $\begin{array}{l}1390947 \\
1661221 \\
(83.7)\end{array}$ & $\begin{array}{l}1637344 \\
1936763 \\
(84.5)\end{array}$ & $\begin{array}{l}1885995 \\
2218267 \\
(85.0)\end{array}$ \\
\hline $\begin{array}{l}\text { Looked after } \\
\text { away from home }\end{array}$ & $\begin{array}{l}845810 \\
924890 \\
(91.4) \\
\end{array}$ & $\begin{array}{l}951771 \\
1041479 \\
(91.4) \\
\end{array}$ & $\begin{array}{l}1043879 \\
1141214 \\
(91.5) \\
\end{array}$ & $\begin{array}{l}1202820 \\
1309117 \\
(91.9) \\
\end{array}$ & $\begin{array}{l}1364676 \\
1476097 \\
(92.5) \\
\end{array}$ & $\begin{array}{l}1461395 \\
1577962 \\
(92.6) \\
\end{array}$ & $\begin{array}{l}1536720 \\
1653238 \\
(93.0) \\
\end{array}$ \\
\hline Not looked after & $\begin{array}{l}237720960 \\
25400801 \\
(93.1)\end{array}$ & $\begin{array}{l}238988487 \\
257053207 \\
(93.0)\end{array}$ & $\begin{array}{l}2362224933 \\
253714954 \\
(93.1)\end{array}$ & $\begin{array}{l}234687637 \\
251542618 \\
(93.3)\end{array}$ & $\begin{array}{l}232233204 \\
248892603 \\
(93.3)\end{array}$ & $\begin{array}{l}228462656 \\
244551180 \\
(93.4)\end{array}$ & $\begin{array}{l}224270740 \\
240310012 \\
(93.3)\end{array}$ \\
\hline
\end{tabular}

Table 2: Exclusions from school of looked-after and non-looked-after children, 2003-04 to 2008-09. These are instances of exclusion and include repeated exclusion of the same students. Rate $=$ rate per thousand exclusions ${ }^{\mathrm{ix}}$.

\begin{tabular}{|c|c|c|c|c|c|c|c|}
\hline & $2002-3$ & $2003-4$ & $2004-5$ & $2005-6$ & $2006-7$ & $2007-8$ & $2008-9$ \\
\hline Number of exclusions & 1819 & 1396 & 2601 & 3046 & 3787 & 3938 & 3853 \\
\hline $\begin{array}{l}\text { Rate looked after 'at } \\
\text { home' }\end{array}$ & - & 242 & 325 & 333 & 358 & 522 & 433 \\
\hline $\begin{array}{l}\text { Rate looked after } \\
\text { 'away from home' }\end{array}$ & - & 264 & 354 & 341 & 380 & 359 & 325 \\
\hline Rate non-looked-after & 50 & 53 & 58 & 60 & 64 & 58 & 50 \\
\hline
\end{tabular}


Table 3: Academic attainment of care leavers over 16 in Scotland: change from 2002-03 to 2007-08

\begin{tabular}{|c|c|c|c|c|c|c|}
\hline & \multicolumn{2}{|c|}{$2002-2003^{x}$} & \multicolumn{2}{|c|}{$2005-2006$} & \multicolumn{2}{|c|}{$2007-2008$} \\
\hline & Home & Away & Home & Away & Home & Away \\
\hline No awards & $67 \%$ & $47 \%$ & $386(55 \%)$ & $242(43 \%)$ & $389(55 \%)$ & $223(39 \%)$ \\
\hline $\begin{array}{l}\text { At least one award at } \\
\text { Level } 3 \text { or higher }\end{array}$ & $33 \%$ & $53 \%$ & $319(45 \%)$ & $320(57 \%)$ & $322(45 \%)$ & $353(61 \%)$ \\
\hline $\begin{array}{l}\text { English and Math at } \\
\text { Level } 3 \text { or higher }\end{array}$ & \multicolumn{2}{|c|}{$27 \%$} & $195(28 \%)$ & $231(41 \%)$ & $182(26 \%)$ & $263(46 \%)$ \\
\hline
\end{tabular}

\footnotetext{
${ }^{\mathrm{i}}$ The framework for school improvement in Scotland is known by the general name, How Good is our School? For more information see: www.hmie.gov.uk/Generic/HGIOS ${ }^{\text {ii }}$ See www.sircc.org.uk/lacsig

iii 'Bairn' is a Scots dialect word used, particularly in north and east Scotland, for 'child'.

${ }^{\text {iv }}$ A co-ordinated support plan is the highest level of intervention where 'significant' additional support needs are identified and where professional support from at least one other agency besides education is indicated. It has statutory backing.

${ }^{v}$ See: www.lookedafterchildrenscotland.org.uk/index.asp

${ }^{v i}$ See: www.nationalcarestandards.org/

vii See: www.sqa.org.uk/sqa/CCC_FirstPage.jsp

${ }^{\text {viii }}$ For information about the Scottish Credit and Qualifications Framework see: www.scqf.org.uk/

ix Source: www.scotland.gov.uk/Topics/Statistics/Browse/School-Education/PubExclusions

$\mathrm{x}$ The total number of care leavers in 2003-03 was 1,138. Only percentages were presented within categories in the statistical report. The proportion gaining both English and maths was not reported by home and away from home.

${ }^{x i}$ Level 3 qualifications are equivalent to GCSE qualifications in he other countries of the UK.
} 